\title{
Palestine's Joining the World Trade Organization
}

\author{
Mohammed I. M. Hamdan ${ }^{1}$, Mohamed Shawky Abd El-Aal ${ }^{1} \&$ Abidin Abdul Hamid Kandil ${ }^{1}$ \\ ${ }^{1}$ Faculty of Economics and Political Science, Cairo University, Cairo, Egypt \\ Correspondence: Mohammed I. M. Hamdan. E-mail: mohamedizz658@gmail.com
}

Received: October 7, 2017

doi:10.5539/ass.v14n1p95
Accepted: October 30, $2017 \quad$ Online Published: December 27, 2017

URL: https://doi.org/10.5539/ass.v14n1p95

\begin{abstract}
The current study attempts to highlight the stages of Palestine's joining the World Trade Organization (WTO) and steps that should be followed by Palestine to join the World Trade Organization from the observer to the member. It also clarifies how Palestine joins the World Trade Organization as a state and then as a customs territory. The problem of this study lies in determining the legal effects of Palestine's joining the World Trade Organization as a state on the one hand and as a customs territory on the other. The study aims at clarifying the stages that Palestine will go through in case of joining the World Trade Organization, the steps that Palestine should take to join the World Trade Organization, and the mechanism that should be followed when Palestine joins the World Trade Organization as a state, and then as a customs territory. The study concluded that Palestine must join the World Trade Organization as a customs territory as soon as possible in order to avoid any discussion about the final legal status of its territories according to the Oslo Accords.
\end{abstract}

Keywords: World Trade Organization, General Agreement of Tariffs and Trade (GATT), State, Customs Territory, Observer, Member

\section{Introduction}

The integration of Palestine into the international commercial community is through the establishment of preferential trade agreements with neighboring states or with other friendly states on a bilateral or regional basis. Such integration can be achieved by joining the World Trade Organization as the main organization interesting in international trade.

\section{The stages and steps of Palestine's joining The World Trade Organization}

Palestine passed several stages in its attempt to join the World Trade Organization, from the British Mandate to the membership of the Observer State that is not a member in the United Nations.

\subsection{First section: the stage of Palestine's joining the World Trade Organization.}

The negotiations on the establishment of the World Trade Organization culminated in the convening of Havana Conference. This conference was concluded by adopting Havana Charter for the establishment of the World Trade Organization. All members of the United Nations were automatically invited to the charter. The Provisional Committee of the World Trade Organization recommended the Economic and Social Council of the United Nations that nonmember states of the United Nations, which interest significantly in the international trade, must be invited, with reference to non- member countries of the United Nations. The Secretary General of the Provisional Committee, Erbek Wyndham White, stated that the state or sovereignty is not a condition for joining. Therefore, the Provisional Committee recommended that Ceylon, Burma and South Rhodesia should be participated. The committee said that these states subject to the political sovereignty of a fully independent UN member concerning matters covered by the charter. Erbek Wyndham White stated that the final decision on Palestine had been left to the UN Economic and Social Council (Mr. E. Wyndham White 1947) where Palestine has been represented at the Havana Conference by the United Kingdom.

Internationally, the British Government was responsible for Palestine from 1923 to 1948 and under the League of Nations (Nations 1920). As such, the United Kingdom represented the interests of the territory of Palestine which was mandated at the Havana Conference for establishing the World Trade Organization in 1947 and the General Agreement on Tariffs and Trade (GATT). The state that did not ratify the Havana Charter is the United States.

Concessions granted to the custom area covering the territory of Palestine were different from those granted to the United Kingdom. Interim Application Protocol has been approved by the United Kingdom. Such protocol led to the activation of the GATT Agreement on behalf of the territory of Palestine, which was commissioned on 20 March 1984 
(Van der Borght and Awwad 2016).

When the United Kingdom notified the United Nations of its intention to finalize its mandate in 1948, this had an impact of Palestine's position in the GATT. The termination of the mandate did not automatically end Palestine's obligations in GATT where the United Kingdom declared that the changes took place were of a political nature and completely outside the control of the United Kingdom (GATT 1949). The United Kingdom stated that Palestine was no longer a member of the GATT, and that Israel was the successor state (GATT 1949). The GATT Contracting Parties did not agree with this view and they felt that the situation could be determined in two legal ways: the first, it was to consider Israel the successor state to Palestine's obligations in the GATT. The contracting Parties rejected this view because the law of succession of states was not clear on this point, and Israel did not give any indication of its willingness to be committed to it(Kunugi 1965). In fact, Israel explicitly rejected this matter. It stated that it did not consider itself bound by the timetable contracted by the United Kingdom as the mandatory power of Palestine (Kunugi 1965, Kunugi 1965). The contracting parties considered that the decision of the United Kingdom to cede its mandate should be interpreted in terms of GATT as an application for withdrawal from the Agreement under article 27. United Kingdom was no longer a contracting party in respect of custom lands that previously included in its jurisdiction such as Palestine(Kunugi 1965). This means that Palestine's obligations expired and that other contracting parties were free to renounce their obligations to Palestine provided that all other contracting parties are notified, and according to the request of Palestine to consult with the contracting parties that have a great interest in this matter (GATT 1949). The British mandate included two areas (GATT 1949). The first was Palestine, which was directly administrated by the United Kingdom. The second was East Jordan that enjoys greater autonomy (Van der Borght and Awwad 2016). This led to the withdrawal of three states from the United Kingdom, which had submitted applications for joining the GATT. These states are Israel, Jordan and Palestine. Israel had not shown its willingness to abide by the General Agreement on Tariffs and Trade (GATT) (GATT 1959). In 1959, Israel requested joining the General Agreement on Tariffs and Trade (GATT) (GATT 1959). The contracting parties agreed to the provisional acceptance of Israel in the same Year (GATT 1959). In 1962, Israel became a contracting party to the GATT (GATT 1961). As for Jordan, the issue of its joining GATT backs to the first days of the World Trade Organization. At a press conference held before the Havana Conference, the Executive Secretary of the Interim Committee included East Jordan as one of the invited countries (GATT 1961). However, in 1994, Jordan requested to become a signatory to the General Agreement on Tariffs and Trade. When the World Trade Organization was established, the application was converted into application to join the WTO in 1995 (WTO 1995). Jordan became a member of the WTO on 11 April 2000 (Agreement 2000). As for Palestine, it was represented at the Havana Conference by the United Kingdom, which negotiated specific concessions to Palestine. However, the abandonment of the mandate served as withdrawal from the GATT. After the establishment of the state of Israel, the West Bank and Gaza Strip were controlled by both Jordan and Egypt respectively until 1967. After the 1967 War, Israel captured the Palestinian territories and largely integrated the Palestinian economy into its economy. Israel's Protectionist economic policy had made all Palestinian imports and exports under full control of Israel, and has hampered the activity of Palestinian enterprises in order to avoid competition with its counterparts (Roy, 1999; Harpaz, 2006). This status served as an incomplete custom union, leading to major trade obstacles to the Palestinian economy (Arnon \& Weinblatt 2001).

In the context of the peace process in 1994, the economic agreements were reached. The Protocol of Economic Relations between the Government of Israel and the Palestine Liberation Organization - Paris Protocol - was signed in 1994 following the Declaration of Principles concerning Interim Self- Government Arrangements (Oslo I Accord). The Paris Protocol represents the formalization of economic realities on the ground. And Exemption Some Palestinian goods from customs fees or to grant them a discount in fees (Amsha, 2011). The transfer of control to the Palestinian people is initiated, and control is transferred in two stages where the agreement on the Gaza Strip and the Jericho area on 4 May 1994 confirmed the Palestinian commercial autonomy within the limits of the agreement in the two areas. These areas were of strategic importance because they represent the main border crossings with Egypt and Jordan. Nevertheless, the actual control of the border crossings remained in the hands of the Israeli authorities. This interim agreement, the Gaza- Jericho Agreement, expanded to include area in the West Bank and Gaza Strip (Oslo II Accord)(Agreement 1995). The areas of Palestinian control were divided into A and B. The civilian authority of the Palestinian National Authority has been granted in these areas. The Paris Protocol was temporary for five years period aimed at enabling the Palestinian National Authority to prepare and arrange its economic affairs prior to final position negotiations. However, the Paris Protocol was not fully implemented, and was not make any significant progress in the final status negotiations after the transitional period ended in 1999.

2.2 The second section: the steps of Palestine's accession to the World Trade Organization.

\subsubsection{First: Joining as an observer}

States endeavors initially to join the World Trade Organization as an observer in the General Council of the 
Organization and its subsidiary bodies in order to be acquainted with the organization and the procedures of negotiation for joining it (Agreement 1996, Stoll \& Schorkopf, 2006). The rules of procedure for the session of the Ministerial Conference and the meetings of the General Council maintain that the representatives of separate states or customs territories may attend meetings as observers at the invitation of the General Council in accordance with the guidelines contained in Annex 2 to these rules (Agreement 1996). Annex 2 distinguishes between two types of observer status: the first observer is assigned to the ministerial meeting. The second is an observer member, where the request can be submitted to the ministerial meeting to which the request was submitted (Agreement 1996). In 1997, the Palestinian National Authority showed interest in joining the international trading system for the first time (Abdullah, 2010). The Palestinian National Authority attended the Hong Kong Ministerial Meeting in December 2005 where a request for obtaining the observer status was submitted and accepted (Agreement 2005, Agreement 2008, Berends, 2008).

Article 4 of Annex 2 to the Rules of Procedure states that: "governments, wishing to submit an application for observer status in the General Council, must send a message to that body, informing that it expresses its intention to commence the negotiations of joining the WTO agreement within a maximum period of five years. The state, wishing to join, provides a description of its current economic and trade policies, as well as any future reforms in these policies. In October 2000, Palestine formally expressed its wish to join the World Trade Organization. It provided instructions to the Permanent Observer Mission of Palestine to the United Nations and other international organizations to contact the General Council of the World Trade Organization in order to request Palestine to be observer status at the World Trade Organization (Agreement 2000). Palestine's officials met with the representatives of various WTO members in September 2009 in Geneva, including representatives from the United States, the European Union, China and Japan (Bahalim, 2009). They also met with the WTO Director-General, Pascal Lamy, to discuss the request (Bahalim, 2009). An official request for obtaining observer status for Palestine was submitted in October 2009, followed by responses to questions from WTO members.

In 2009, the Palestinian government declared its goal of membership in the World Trade Organization (WTO) clearly (Bank 2011), to end the occupation and the establishing of the state, and went through some processes to help them obtain their membership in the World Trade Organization. The National Task Force is the advisory Palestinian team of the World Trade Organization (NTF) which was formed by including representatives from the public and private sectors, and have a meeting every two months with the chairman of the Minister of National Economy. The team's duty is to provide political guidelines to the Palestinian government and advise them on how to become a member of the NTF (Bank 2010). The Technical Advisory Group is the operational team which comprises of professionals from public and private organizations. This team holds meetings every month and is responsible for implementing all the policies. The transparency committee includes members of the national task force and the technical advisory team. Its mission is to review the transparency rules applied in Palestine in order to achieve compliance with the special transparency requirements. The World Trade Organization (WTO) Unit of the Ministry of National Economy consists of several expert staff to provide technical support to the Technical Advisory Group and the National Task Force, and to advise the Minister of Economy on all issues related to the World Trade Organization. In addition, there is a process of legislative and institutional reform - such as the revision of the regulatory framework of the telecommunications sector, the drafting of new intellectual property laws - to comply with WTO rules (Bank 2009).

In November 2009, Palestine was allowed to participate as a special observer at the Ministerial Conference held in Geneva (Agreement 2009). However, its request to become an observer member was unable to mobilize the necessary support to reach a consensus decision in accordance with WTO Practice. Although the Agreement of Marrakesh establishing the World Trade Organization (The Uruguay Round Agreement)(Agreement 1999) requires only approval of two - thirds majority of WTO members (Agreement 1999), Israel and the United States opposed this request.

The Palestinian request for obtaining the status of observer to the World Trade Organization was re-submitted in April 2010 with the hope that it would be approved at the May 2010 meeting of Ministerial Council (WTO 2009). For reasons far from the General Council, the request did not include on the agenda of the meeting. These procedural wrangles indicate the politically sensitive nature of the demand. Although the WTO is proud to be an organization based on legal rules, the process of joining is a political process by nature (Lee and Ullrich 2009). Although this matter is not a legal requirement according to the Agreement of Marrakesh, the customary legal basis is to take all decisions on the basis of consensus (Lee \& Ullrich, 2009), meaning that the United States must be supportive of the resolution (Wikileaks, 2010).

A delegation headed by the Deputy Director - General of the World Trade Organization, Alejandro Garra, visited Palestine in June 2010. The visit served as a recognition of the progress made by the Palestinian Ministry of National Economy in preparation for joining the World Trade Organization. In December 2013, Palestine attended - as a special observer - the $9^{\text {th }}$ session of the ministerial conference held in Bali, Indonesia (Agreement 2013). Although procuring 
observer member is an essential step to join the WTO, the success of this initial step depends, for political reasons, largely on the selected procedural method to join organization.

2.2.2 Second: joining as a member.

The members of the World Trade Organization are either original members or joined ones (Agreement 1999). Palestine was represented in the original negotiations of the Havana Charter of the World Trade Organization and the General Agreement on Tariffs and Trade (GATT). It became a founding member of the GATT where it was represented through the United Kingdom. When the United Kingdom abandoned its mandate, the contracting parties considered this abandonment as Palestine's withdrawal legally. Palestine did not request the re- entry of the GATT in 1947. Therefore, it could not be a member of the World Trade Organization.

Palestine is now seeking to join the World Trade Organization where procedures and conditions differ from those of the GATT in 1947 (Lanoszka, 2001). Joining the World Trade Organization of the new member requires the acceptance of the new member of all the rules of the Uruguay Round Agreement (one project). Palestine must join the World Trade Organization in accordance with article 1/12 of the Marrakesh Agreement (Gallagher, 2005), which states: "any state or a separate customs territory, which enjoys full autonomy in managing its foreign trade relations or other matters stipulated in this agreement and in the Multilateral Trade Agreement, may join this agreement according to agreed conditions with the World Trade Organization.

Article 12 of the Agreement states that joining the World Trade Organization will be based on mutually agreed terms between the applicant and the WTO members. In fact, this means negotiating on terms between the applicant and the current members wishing to engage in bilateral talks with the joined member. Article 12 does not provide legal criteria for joining process. Thus, every joining process is different from another. Furthermore, in the context of the procedures to be used for joining requirements, article 12 does not specify any clear steps, and does not provide any advice. Also, the WTO has no clear rules on membership, and the circumstances and elapsed time may vary considerably (Evenett, 2005). Article 12 does not stipulate any rules or principles for joining negotiations. Additionally, it does not indicate terms that could be agreed between applicant and WTO members (Qin, 2003; Nguyen, 2008). History knows that such terms are not relevant to the WTO at all.

\section{Palestine's joining the WTO as a state.}

The article 12 of the Marrakesh Agreement allows Palestine to join as a state or separate customs territory. Palestinian President Mahmoud Abbas issued the Presidential Decree No. 1/2013 announcing the change of status from the Palestinian National Authority to the State of Palestine (WAFA 2013). The state of Palestine has been recognized by 138 of member states of the United Nations. The decisions of joining the WTO have been taken according to article 12/2 of the Marrakesh Agreement. This article stipulates that: "the Ministerial Conference takes the decisions of joining and approves the terms of joining agreement by a two- thirds majority of the members of the Organization". On the assumption that the countries recognize Palestine as state in the UN General Assembly would be able - under the right economic conditions - to vote for Palestine's membership in the World Trade Organization, the result is a positive two- thirds majority for Palestine. Thus, it will receive 111 votes of 159 votes. It is expected that Israel will object to such scenario, but this objection contradicts Israel's long- standing policy in the international trading system. Israel has been a strong supporter of the trading club since its joining the GATT, even in difficult or politically sensitive circumstances. An example of this is the treatment of Israel with joining Egypt - the United Arab Republic as it was called at that time - in 1970. Israel will not confuse political considerations with the economic objectives of the WTO. To demonstrate this, it issued a declaration to Egypt. However, the formulation of this declaration remained general where Israel declared that it supports the accession of any country to the GATT provided that it is prepared to fulfill the obligations of the agreement (GATT 1962). When Israel came under pressure to withdraw from the working group on Egypt's joining, Israel resisted pressure from the Secretary - General of the GATT and some of the strong contracting parties of the GATT. Israel stressed that GATT should be a non - political organization, and these Egyptian pressures will form a dangerous precedent(GATT 1962). When Israel questioned Egypt on political issues such as the Arab boycott, the Egyptian negotiator stressed that such matters were the result of political conflict and were not the subject of discussion under the General Agreement on Tariffs and Trade (Van der Borght and Awwad 2016). In accordance with previous procedures established by Israel and confirmed by Egypt, Israel should avoid political discussions within the World Trade Organization. Nevertheless, it voted against joining but would not be able to prevent it if the decision - taking rules were followed. Israel would have the option of resorting to the article (13) of the Marrakesh Agreement - the so-called non- application of multilateral trade agreements between specific members.

It seems, however, that this scenario will fail, and the reality in WTO decision - making does not reflect the procedures of the agreement where decisions in the General Council have been taken by consensus (WTO 1995). Therefore, voting became the exception and decision - making by consensus became the norm. There is only one case for joining 
on the basis of voting, the case of Ecuador (WTO, 1995; Steger, 2000). The special circumstances of this one case decrease its value (Footer, 2006). Moreover, this case is preceded by the implementation of the decision of the General Council in decision - making by consensus concerning the joining of the states. In fact, decisions on joining are taken by consensus. Thus, the de facto veto of current members of the World Trade Organization has been established in order to impede the admission of new applicants (Van der Borght and Awwad 2016). Given the continued Israeli occupation of the state of Palestine, it is inconceivable that Israel would accept Palestine's joining the World Trade Organization as a sovereign state.

\section{Palestine's joining The World Trade Organization as a customs territory.}

Given the reality of WTO's decisions - making, it is likely that Palestine may seek to join the WTO as a separate customs territory. By choosing this path, Palestine will use the strategy that other WTO member states have tried to avoid for discussing any final legal status of its territory in accordance with the Oslo Accords. This makes it possible to have a less politicized process in line with the diplomatic tradition of the GATT that prefers a compromise instead of a strict legal outcome (Van der Borght and Awwad 2016). Palestinian Minister of Economy, Bassem Khoury, said that Palestine could achieve full membership in five years, even without establishing a state such as Hong Kong, Taiwan and Macao (Ammad Bahalim 2008).

There is a useful comparison to the case of Jordan. Jordan chose to apply to join the GATT in 1994, then return to apply to become a membership in World Trade Organization in 1995. The general council of the World Trade organization approve the application of Jordan to become a state after studied their application in 17 December 1999 (AlKhaldi, 2015).

Also there is a useful comparison to the case of Taiwan (O'Quinn 1996). It has chosen to give priority to WTO membership on promoting the diplomatic recognition of its status as a sovereign state through the joining process. It has accepted terms aimed at avoiding conflict with the People's Republic of China by calling itself "a separate Taiwan customs territory", [Bing, Kinmen, Matsu (Chinese Taipei)], and avoiding carefully any reference to sovereignty or state. Taiwan has been joined WTO by the Director - General's good offices. This led to agreement between China and the People's Republic of China on Taiwan's joining WTO despite differences over sovereignty over Taiwan territory.

Palestine takes a cautious approach by defining itself as "a separate customs territory on the road to statehood" (Van der Borght \& Awwad 2016). Most UN documents referred to Palestine as "an occupied Palestinian territory" before the recognition Palestine as a non - member observer state. However, after acceptance by the United Nations, the term "state of Palestine" was used for the purpose of the United Nations. The use of the term Palestine became prevalent. As the World Trade Organization's request precedes this development, the margin of the document showed that the term Palestine refers to the West Bank and the Gaza Strip. In order to avoid diplomatic obstacles of terms, the explanatory margin continues to use the term Palestine to facilitate reading without prejudice to the question of the status (O'Quinn 1996). Accordingly, the Palestinian demand is based on the assurance that Palestine is a separate territory, and thus it is eligible to consider membership under article (12).

The application of joining World Trade Organization as a separate customs area creates a new challenge for Palestine because this qualification is defined by the Marrakesh Agreement. When the establishment of the state outside the framework of the World Trade Organization is decided, the WTO decides eventually to qualify the state as a separate customs area in accordance with article (12) of the Marrakesh Agreement. The decision requires the separate ad hoc territory to be fully independent in the management of its external trade relations and other matters stipulated in the Marrakesh Agreement and the Multilateral Trade Agreement of the World Trade Organization. Palestine is a fully independent separate customs area so that it can develop its external trading relations and manage its domestic economic affairs.

\section{Conclusion}

Palestine has the right to join the World Trade Organization after obtaining resolution (67/19) of the United Nations General Assembly to grant Palestine the status of observer non- member state of the United Nations. It is preferable for Palestine to start joining the World Trade Organization in order to avoid any discussion on the legal status of its territories in accordance with Oslo Accords. This makes the process less politicized in line with the diplomatic tradition of GATT. This tradition prefers a compromise instead of strict legal outcome. Within next five years, it has the right to become a full member as a state without the establishment of a state in the United Nations.

\section{References}

Agreement (1995). Palestinian-Israeli Interim Agreement on the West Bank \& Gaza Strip. https://doi.org/10.1177/0967010695026004014

Agreement (2000). Letter of Director-General regarding the Notification of Acceptance and Entry into Force of the 
Protocol of Accession of the Hashemite Kingdom of Jordan to the Marrakesh Agreements Establishing the World Trade Organization WTO.

Agreement, W. (1996). Rules of Procedure for Sessions of the Ministerial Conference and Meetings of General Council-Annex II: Guidelines for Observer Status for Governments in the WTO.

Agreement, W. (1996). Rules of Procedure for Sessions of the Ministerial Conference and Meetings of the General Council.

Agreement, W. (1999). "Marrakesh Agreement Establishing the World Trade Organization, Apr. 15, 1994." The legal texts: The results of the Uruguay round of multilateral trade negotiations 4: 1867

Agreement, W. (2000). "Palestine-Request for Observer Status: Communication from Palestine." WT/L/770

Agreement, W. (2005). Request for Observer Status by the Palestinian Liberation Organization on behalf of the Palestinian Authority. S. S. o. t. M. Conference. Geneva.

Agreement, W. (2008). Request for Observer Status by the Palestinian Liberation Organization on behalf of the Palestinian Authority. S. S. o. t. M. Conference. Geneva.

Agreement, W. (2009). "Seventh Session of the Ministerial Conference."WT/L/775.

Agreement, W. (2013). "Ninth Session of the Ministerial Conference, Request for Observer Status by Palestine."WT/L/884.

AlKhaldi, R. (2015). "The Endeavours of the Palestine's accession the World Trade Organization : Evaluation and Lession " Palestine Economic Policy Research Insitute - Mas: 27.

Ammad Bahalim, T. B., Paige McClanahan, Jessica Thorn, Daniel Villar, Paige McClanahan (2009) Palestinians Seek Observership Status at the WTO. 13, 1.

Ammad Bahalim, T. B., Paige McClanahan, Jessica Thorn, Daniel Villar, Paige McClanahan. (2008). 58 Despite Obstacles, EU Expects Russia to Join WTO This Year. Bridges.

Geneva, International Centre for Trade and Sustainable Development (ICTSD). 12: 1.

Amsha, M. K. A. (2011). "The World Trade Organization and the efforts of the State of Palestine to join to the agreements, obligations, rights and procedures." Arab Democratic Center.

Arnon, A., \& Weinblatt, J. (2001). Sovereignty and economic development: the case of Israel and Palestine. The Economic Journal, 111(472), 291-308

Bank, T. W. (2011). Building the Palestinian State: Sustaining Growth, Institutions, and Service Delivery. Economic Monitoring Report to the Ad Hoc Liaison Committee.

Bank, W. (2009). A Palestinian State in Two Years: Institutions for Economic Revival. Economic Monitoring Report to the Ad Hoc Liaison Committee, World Bank.

Bank, W. (2010). The Underpinnings of the Future Palestinian State: Sustainable Growth and Institutions._Economic Monitoring Report to the Ad Hoc Liaison Committee.

Berends, G. (2008). Fear and loading in West Bank/Gaza: the state of Palestinian trade. J. World Trade 42: 151

Evenett, S. J. (2005). "WTO accession: lessons from experience."

Footer, M. E. (2006). An institutional and normative analysis of the World Trade Organization, Nijhoff.

Gallagher, P. (2005). The first ten years of the WTO: 1995-2005, Cambridge University Press.

GATT (1962). Summary Record of the Ninth Meeting Held at the Palais des Nations. Geneva, GATT: 135.

GATT (1962). Summary Record of the Ninth Meeting Held at the Palais des Nations. Geneva, GATT: 790.

GATT, A. (1949). The Position of Palestine in Relation to the Agreement, Note by the Secretariat. GATT/CP.3/17. Geneva, GATT.

GATT, A. (1949). Summary Record of the Eleventh Meeting. GATT/CP.3 /SR.11. Geneva, GATT.

GATT, A. (1959). Accession to the General Agreement, Request by Israel. L/968. Geneva, GATT.

GATT, A. (1959). Declaration on the Provisional Accession of Israel-Entry into Force. Geneva, GATT. L/1040.

GATT, A. (1961). Accession of Israel-Entry into Force of the Protocol for the Accession of Israel-Note by the Executive Secretary. L/1795. GATT. Geneva.

Harpaz, G. (2006). "The New Israeli Anti-Dumping Legislation: One More Modest Step in Israel's Gradual Advance 
from Unilateralism Towards Trans-National Co-operation." 238

Kunugi, T. (1965). "State Succession in the Framework of Gatt." The American Journal of International Law 59(2): 279.10.2307/2196968

Lanoszka, A. (2001). World Trade Organization Accession Process. The J. World Trade 35: 575.10.1023/A:1011892125917

Lee, D. \& H. Ullrich (2009). "The Diplomacy of WTO Accession." The Hague Journal of Diplomacy 4(1): 1-5

Mr. E. Wyndham White, E. S. o. t. P. C. o. t. U. N. (1947). Trade and Employment on Friday. Geneva, European Office of the United Nations Information Center 234: PP.10-11.

Nations, L. o. (1920). Mandate for Palestine. San Remo Conference.

Nguyen, N. (2008). "WTO Accession at Any Cost-Examining the Use of WTO-Plus and WTO-Minus Obligations for Least-Developed Country Applicants." Temp. Int'l \& Comp. LJ 22: 243

O'Quinn, R. (1996). "Bringing Both China and Taiwan into the World Trade Organization." CHINESE YEARBOOK OF INTERNATIONAL LAW AND AFFAIRS 14: 19-37

Qin, J. Y. (2003). WTO-Plus Obligations and Their Implications for the World Trade Organization Legal System. J. World Trade 37: 483

Roy, S. (1999). De-development revisited: Palestinian economy and society since Oslo. Journal of Palestine studies 28(3): 64-82. DOI: $10.2307 / 2538308$

Samir Abdullah, W. T. O. (2010). Palestine Economic Policy Research Institute. Palestine: 10.

Steger, D. P. (2000). The World Trade Organization: A new constitution for the trading system.

Stoll, P.-T. \& Schorkopf, F. (2006). World economic order, world trade law. Leiden: Martinus Nijhoff. https://doi.org/10.1163/ej.9789004144965.i-292.2

Van der Borght, K. \& Awwad, H. (2016). Palestine and the World Trade Organization: A Legal Roadmap for Accession. The Palestine Yearbook of International Law Online 18(1): 147. https://doi.org/10.1163/2211-6141_007

Van der Borght, K. \& Awwad, H. (2016). Palestine and the World Trade Organization: A Legal Roadmap for Accession. The Palestine Yearbook of International Law Online 18(1): 148. https://doi.org/10.1163/2211-6141_007

Van der Borght, K. \& Awwad, H. (2016). Palestine and the World Trade Organization: A Legal Roadmap for Accession. The Palestine Yearbook of International Law Online 18(1): 155. https://doi.org/10.1163/2211-6141_007

Van der Borght, K. \& Awwad, H. (2016). Palestine and the World Trade Organization: A Legal Roadmap for Accession. The Palestine Yearbook of International Law Online 18(1): 156. https://doi.org/10.1163/2211-6141_007

Van der Borght, K. \& Awwad, H. (2016). Palestine and the World Trade Organization: A Legal Roadmap for Accession. The Palestine Yearbook of International Law Online 18(1): 157. https://doi.org/10.1163/2211-6141_007

WAFA (2013). Presidential Decree Orders Using 'State of Palestine' on all Documents Archived 15 January 2013 at the Wayback Machine.

WIKILEAKS (2010). Palestinian Authority Request for WTO Observer Status: USTR Meetings with Palestinian Officials and Private Sector.

WTO (1995). Accession of Ecuador. 16/8/1995.

WTO (1995). Decision-Making Procedures under Articles IX and XII of the WTO Agreement.

WTO, A. (1995). Accession of Jordan: Communication from Jordan. WT/ACC/JOR/1. WTO. Geneva, WTO.

WTO, A. (2009). Palestine-Request for Observer Status: Communication from Palestine - Application for Observership in the General Council and its Subsidiary Bodies. WT/L/792.

\section{Copyrights}

Copyright for this article is retained by the author(s), with first publication rights granted to the journal.

This is an open-access article distributed under the terms and conditions of the Creative Commons Attribution license (http://creativecommons.org/licenses/by/4.0/). 